\title{
Developing the Models of Service Quality Gaps: A Critical Discussion
}

\author{
Arash Shahin \\ Department of Management, University of Isfahan \\ Hezar Jarib St., Isfahan 81746-73441, Iran \\ Tel: 98-311-793-2040Ｅ-mail: arashshahin@hotmail.com \\ Monireh Samea \\ Department of Management, University of Isfahan \\ Hezar Jarib St., Isfahan 81746-73441, Iran \\ Tel: 98-311-793-2040Ｅ-mail: monirehsamea@yahoo.com
}

\begin{abstract}
High service quality is imperative and important for competitiveness of service industry. In order to provide much quality service, a deeper research on service quality models is necessary. There are plenty of service quality models which enable managers and practitioners to identify quality problems and improve the efficiency and profitability of overall performance. One of the most influential models in the service quality literature is the model of service quality gaps. In this paper, the model of service quality gaps has been critically reviewed and developed in order to make it more comprehensive. The developed model has been verified based using a survey on 16 experts. Compared to the traditional models, the proposed model involves five additional components and eight additional gaps.
\end{abstract}

Keywords: Quality, Service Quality, Gaps, Models

\section{Introduction}

Service quality is considered as a critical dimension of competitiveness (Lewis, 1989). Providing excellent service quality and high customer satisfaction is the important issue and challenge facing the contemporary service industry (Hung et al., 2003). Service Quality is an important subject in both public and private sectors, in business and service industries (Zahari et al., 2008). It is the extent to which a service meets or exceeds customer needs and expectations (Lewise and Mitchell, 1990; Dotchin and Oakland, 1994a; Asubonteng et al., 1996: Wisniewiski and Donnelly, 1996; Seilier, 2004; Zahari et al., 2008). During the past two decades, service quality has become a major area of attention to practitioners, managers and researchers because of its strong impact on business performance, lower costs, return of investment, customer satisfaction, customer loyalty and gaining higher profit (Leonard and Sasser, 1982; Cronin and Taylor. 1992; Gammie, 1992; Hallowell, 1996; Chang and Chen, 1998; Gummesson, 1998; Lasser et al., 2000; Newman, 2001; Sureshchander et al., 2002; Seth and Deshmukh, 2005). The rapid development and competition of service quality, in both developed and developing countries has made it important for companies to measure and evaluate the quality of service encounters (Brown and Bitner, 2007).

Several conceptual models have been developed by different researchers for measuring service quality. It is envisaged that conceptual models in service quality enable management to identify quality problems and thus help in planning for the launch of a quality improvement program, thereby improving the efficiency, profitability and overall performance (Seth and Deshmukh, 2005). Some of the most influential models in the service management literature focus on the concept of service quality gap. Service quality gap is defined as the difference between customer expectations and perceptions of service. If expectations are greater than performance, then perceived quality is less than satisfactory and customer dissatisfactions occurs (Parasuraman et al., 1985; Lewis and Mitchell, 1990). In recent years, greater emphasis has been placed on understanding the role of expectations (Pitt and Jeantrout, 1994), given the fact that consumers' expectation of quality are increasing (Dotchin and Oakland, 1994b; Haywood-Farmer and Stuart, 1990), and people are becoming more discerning and critical of the quality of service that they experience (Philip and Hazlett, 1997). According to Boulding et al. (1993), expectations are "pre-trial beliefs about a product or service". 


\section{MInstitute Macrothink $_{\text {Int }}$}

The aim of this paper is to develop and modify the model of service quality gaps based on a critical discussion in order to make it more comprehensive. Although the traditional models identify determinants and elements of service quality and service quality gaps, it seems still there is a potentiality to further develop them. In the following, some of the well known traditional models of service quality gaps are introduced and a more comprehensive model is proposed based on a critical discussion.

\section{Models of service quality gaps}

\subsection{Service quality gaps model by Parasuraman et al. (1985)}

The most well known model is the model of Parasuraman et al. (1985) which is widely utilized in the literature. The model attempts to show the salient activities of the service organization that influence the perception of quality. Moreover, the model shows the interaction between these activities and identifies the linkages between the key activities of the service organization or marketer which are pertinent to the delivery of a satisfactory level of service quality. The links are described as gaps or discrepancies: that is to say, a gap represents a significant hurdle to achieving a satisfactory level of service quality (Ghobadian et al., 1994).

Parasuraman et al. (1985) proposed that service quality is a function of the differences between expectation and performance along the quality dimensions. They developed a service quality model (Figure 1) based on gap analysis. The gaps include (Seth and Deshmaukh, 2005):

Gap 1: Customer expectation-management gap. This gap addresses the difference between consumers' expectations and management's perceptions of service quality.

Gap 2: Management perception-service quality specifications gap. This gap addresses the difference between management's perceptions of consumer's expectations and service quality specifications, i.e. improper service-quality standards.

Gap 3: Service quality specification-service delivery gap. This gap addresses the difference between service quality specifications and service actually delivered, i.e. the service performance gap.

Gap 4: Service delivery-external communication gap. This gap addresses the difference between service delivery and the communications to consumers about service delivery, i.e. whether promises match delivery.

Gap 5: Expected service-perceived service gap. This gap addresses the difference between consumer's expectation and perceived service. This gap depends on size and direction of the four gaps associated with the delivery of service quality on the marketer's side.

According to this model, SERVQUAL scale has proposed by Parasuraman et al.(1988) for measuring Gap 5. Parasuraman et al. (1985) mentioned ten factors for evaluating service quality (including tangible, reliability, responsiveness, courtesy, credibility, security, accessibility, communication and understanding the customer). These ten factors are simplified and collapsed into five factors. These five dimensions are stated as follows (Van Iwaarden et al., 2003; Shahin, 2006):

1) Tangibles. Physical facilities, equipments and appearance of personnel.

2) Reliability. Ability to perform the promised service dependably and accurately.

3) Responsiveness. Willingness to help customers and provide prompt service.

4) Assurance (including competence, courtesy, credibility and security). Knowledge and courtesy of employees and their ability to inspire trust and confidence.

5) Empathy (including access, communication, understanding the customer). Caring and individualized attention that the firm provides to its customers.

The SERVQUAL approach contains a questionnaire that evaluates five generic service dimensions or factors through 22 questions, evaluating both expectation and performance using a seven point Likert scale. This approach evaluates service quality by calculating difference (gap) between customer expectations and perceptions (service quality= P - E). 'P' denotes customer perception of service or performance and 'E' denotes expectations before a service encounter deliver the actual service (Lewis and Booms, 1983; Parasuraman et al., 1985). If the answer is negative, then dissatisfaction occurs, otherwise, the Service Quality is achieved. This equation is usually called gap analysis (Zahari et al., 2008), but as it was emphasized, this approach only measures gap 5 .

\subsection{Internal service quality model by Frost and Kumar (2000)}

Frost and Kumar (2000) developed an internal service quality model. The model (Figure 2) evaluates the 


\section{Ml Macrothink}

dimensions, and their relationships which determine service quality gaps among internal customers (front-line staff) and internal suppliers (support staff) within a large service organization. The gaps are as follows:

Internal gap 1: Difference in support staff's perception (internal supplier) of front-line staff's expectation (internal customers).

Internal gap 2: Difference between service quality specifications and the service actually delivered resulting in an internal service performance gap.

Internal gap 3: Difference between front-line staff's expectations and perceptions of support staff's (internal supplier) service quality. This is the gap which focuses on the front-line staff (internal customers).

\subsection{Model of Service Quality Gaps by Luk and Layton (2002)}

Luk and Layton (2002) developed the traditional model of Parasuraman et al. (1998) by adding two more gaps. They reflect the differences in the understanding of consumer expectations by manager and front-line service providers and the differences in consumer expectations and service providers' perception of such expectations. This model is illustrated in Figure 3.

\section{Critical discussion and development of the models of service quality gaps}

The service quality gaps models can be criticized on both methodological and conceptual grounds (Carman, 1990; Cronin and Taylor, 1992; Teas, 1993; Brown et al., 1993). Cronin and Taylor (1992) proposed that there is a lack of evidence supporting the expectation-performance gap as a predictive measure of service quality. They believe that assessing customer perception is enough for evaluating service quality and it is unnecessary to measure customer expectations in service quality research. They oppose evaluating service quality by calculating the difference between customer perceptions and customer expectations (P-E). Indeed, they define Service Quality as a customer Perception (of Performance only) without expectations. They proposed that the performance based measurement approach (SERVPERF) is more in conformance with the existing attitude and customer satisfaction literature and is superior to the perception-expectation gap approach.

Teas (1993) questioned the validity of perception-expectation gap with conceptual and operational problem in the definition of the expectation. While perception $(\mathrm{P})$ is definable and measurable in a straightforward manner as the customer belief about service is experienced, expectation (E) is subject to multiple interpretation by different authors/ researchers (e.g. Babakus and Inhofe, 1991; Dabholkar et al., 2000; Gronroose, 1990; Teas, 1993, 1994). They believe that expectation concept is doubtful and conceptualized owing to there are plenty definition for the term expectation in service quality literature where it is defined as 'normative expectation' with concern to organization constraints such as human resource or facilities and equipments limitation or 'ideal expectation' without any concern to limitation and constraint, it means what the customer would expect from excellent service. Initially, Parasuraman et al $(1985,1988)$ defined expectation as "desire or wants of customer"; what they feel a service provider should offer rather than would offer (Jain and Gupta, 2004).

Brown et al. (1993) raised psychometric concerns regarding the use of difference score and felt that the gap model would display poor reliability, because expectation and perception could be positively correlated. They also suggested that if the statistical variance of performance score and expectation score are different, any tests of statistical significance would become more complex. The other criticizer claims that SERVQUAL is not applicable to a wide variety of service contexts as the common tool for evaluating service quality (Carman, 1990).

The above explanation provides a critical discussion of the traditional models, but it is not convincing and it seems that this model still needs to be further developed. In the following, other shortcomings in gaps models are addressed and a model is developed based on the discussion. Considering the critical discussion, more gaps are added to the previous models. The proposed model is illustrated in Figure 4 and the added components, gaps and links are highlighted. The new components which are proposed to be fitted in to the model include:

- Ideal service standards;

- Service quality strategy and policy;

- Translation of service quality strategy and policy into service quality specifications and service design;

- Management perceptions of customer perception; and

- Employee perceptions of customer perception.

As it is addressed, eight new gaps are determined as 2, 3, 4, 5, 11, 12, 13 and 14.

The proposed gaps are verified using a survey on 16 experts including nine experts from universities and seven 


\section{MInstitute Macrothin $^{\text {Int }}$}

managers of non-governmental service organizations. Before the experts begin filling out the questionnaires, the definitions of the new gaps and the reasons for their inclusion in model are clearly explained to each of them. In order to confirm the consistency of the experts' opinions on the corresponding results, the binomial test is used to test the null hypothesis of 'There are no differences among experts' opinions'. Each expert indicated his/her opinion by selecting 'Agree' (1) or 'Disagree' (0) for each gap. The test proportion is assumed as 0.50 denoting that at least 50 percent of the experts are expected to agree on the gaps. The results are represented in Table 1. As it is clear, the significance levels are all smaller than 0.05 and the test proportion $(0.50)$ is less than the observed proportions and therefore, it is concluded that the null hypothesis is rejected and there is difference between the experts' opinions. According to the Agreed portions, which are all greater than 0.80, it is argued that the experts mostly agree on the proposed gaps with a confidence level of 0.95 .

\section{Discussion}

The proposed model of service quality gaps consists of five new components and eight new gaps (one is changed). In the following, the new components and new gaps are further described and discussed.

Service quality strategy and policy is one of the items, which is added to the traditional models. Strategy relates the service organization to its environment and defines the way it wants to compete. Service quality strategy outlines the organization's competitive scope and its concept of quality, through a selection of, and positioning on, the fundamental quality dimensions it wants to compete with (e.g. tangibles and empathy).

Quality dimensions are correlated (Parasuraman at al., 1988, 1993) and, sometimes, an improvement in one may be achieved only at the expense of another (Garvin, 1987). The challenge is to choose a balanced combination and positioning (Garvin, 1987; Haywood-Farmer, 1988). Highly concentrating on some dimensions may also constitute an appropriate strategy, but may lead to disaster (Haywood-Farmer, 1988).

Finally, service quality strategy is a set of guidelines that provides orientations for everyone in the organization. It should be thoroughly communicated; should be meaningful for personnel; and should distinguish the organization from others. A clearly designed and stated service quality strategy is considered as the starting point at strategy formulation. Indeed, the failure to create a service quality strategy cause in failure to create customer oriented services. It is important for managers to design strategies based on specific customer expectations and their true perception of customer perceptions and expectations (as it is illustrated in Figure 4), so it can be very profitable for organization with paying more attention to the customer. The service quality strategy includes articulating a clear company's vision, especially as it relates to service quality; setting specific mid-long term objectives; and making segmentation and targeting decisions. Failure to forge and communicate a coherent service quality strategy is a serious service quality gap. Therefore, Gap 2 is defined as "The difference between management perceptions of customer expectations and service quality strategy".

Translation of service quality strategy and policy into service quality specifications is the other item that is added to the traditional models. A strategy management framework begins with the articulation of the service corporation's strategic objectives (the strategy map). Performance measures are then tracked and targets are clarified for these same strategic objectives. A set of programs or action plans are established to attain the performance targets (the strategic initiatives). This process runs counter to management literature that advocates moving from strategy to initiatives to measurement. Therefore, it is important to measure how far the strategies and policies are from managers' perceptions (new Gap 2) and how far the specifications, procedures and standards are from the policies and strategies (new Gap 3). In the traditional models of service quality gaps, management perception of customer expectations directly influence service quality specifications (Figure 3), but in the developed model, management perception of customer expectations and also customer perceptions are guidelines for service quality strategy and policy; then these strategies and policies determine service quality specifications (Figure 4). Specifications, along with the strategic quality dimensions, are useful to define what quality is. It is important to determine service quality specifications with respect to service strategy dimensions. Gap 3 refers to the lack of relationship between service quality specifications and service quality strategies. This gap is defined as "The difference between service quality strategy and service quality specifications".

"Ideal standards" is one of the items added into the traditional models. While it is necessary to have a past-experience from the service, it is not possible to ask a customer (about his/her expectation from the service) who does not have any experience previously. Expectations can also be defined as the ideal standards that customer bears in his/her mind without an experience basis. Therefore, it is decided to add the component of "ideal standards" into the developed model (Figure 4).

Specifications, along with the strategic quality dimensions, are useful to define what quality is. Specifications are required to guide personnel in their activities. Specifications are also required as a means of comparisons for 


\section{MInstitute ${ }^{\text {Math }}$}

effective quality evaluation. Setting adequate specifications does not mean total standardization, so it requires an specification drive from ideal standards as described above in order to concentrating the customer's ideal standards and have total standardization. Based on such explanation, Gap 4 addresses how much specifications are far from ideal standards that customer bears in his/her mind. The lack of analysis, design and definition of ideal standards causes this gap. This gap is defined as "The difference between ideal standards and service quality specifications".

In order to set correct specifications, it is important to pay attention to the external communications. In external communications, it is important to use communication means to inform, persuade and educate the customer and also to get the information about some specifications that must be set by organizations to design a customer-oriented service and to have better external communications. Lack of such effort may result in service quality gap. This gap (i.e. Gap 5) is defined as "The difference between external communications and service specifications".

"Management perceptions of customer perceptions" is the other component added in to the traditional models. In the traditional model of service quality gaps, Gap 1 is defined as the difference between customer expectations and management perception of the customer expectations. Customer perception is also important because it shows what the customer actually perceive of service, and his/her perception in comparison with his/her perception can show customer satisfaction, so the need for managers to access customers' expectations and their perceptions of the quality provided should be emphasized. This is compatible with the investigation of Shahin et al. (2006) in which, the model of service quality gaps was integrated with the Six Sigma methodology and one additional component and two additional gaps were added into the traditional models in order to facilitate the computation of Sigma quality level. Managers should pay more attention to service process and something that customer finally perceives as service delivery. If they left service process to its own way, they remain blind to what customers actually perceive and on the other hand, how their employees performance is in service process, because perceived service is directly influenced by service delivery and service delivery is the consequence of employee performance. It is important to note that regarding the importance-performance analysis (IPA) framework, managers and decision makers should not only focus on what is important to customers, but also they should consider how their feeling about the actual delivered products/services is (Shahin, 2009). Some of the 'deices and causes for this blindness are managers' education, habits developed over time and company policies and procedures, especially relating to marketing research and communication (Zemek and Schaaf, 1989; Zeithaml at al., 2001). Gap 11 means a management lack of understanding of customers' perceptions of the service, motivated by both lack of initiatives to listen to customers (Zemke and Schaaf, 1989) and by a lack of correct understanding when these initiatives are taken (Parasuraman at al., 1985). Therefore, Gap 11 is defined as "The difference between customers' perceived service and management perceptions of customer perceptions".

As management perception of customer expectation influences service strategy, management perception of customer perception also influences service strategy. With concentrating on both customer expectations and perceptions, managers are able to understand customer satisfaction. Consequently, such correct information prevents them to make wrong decisions and choosing inappropriate strategies and policies. If it does not happen, Gap 12 appears and is defined as "The difference between management perceptions of customer perceptions and service strategy".

"Employee perceptions of customer perceptions" another component added into the traditional models. Similar to Gap 11, Gap 13 consists of a discrepancy between the customer perceived service and employee perceptions of customers perceptions. This gap directly affects the service offered, and when it is nil, it implies that employee has a correct imagination of the customers' perceptions. In the traditional model of service quality gaps, Gap 6 is defined as the difference between customer expected service and employee perception of customer expectations, but it is important that employees understand customer perceptions of service offered. It can result in paying more attention by them in service process in order to achieving customer satisfaction. Therefore, Gap 13 is defined as "The difference between the customer perceptions and employee perceptions of customer's perceptions".

It is important for managers to prepare facilities to improve employee's ability in developing quality relationship with customers and understanding their expectations and perceptions of the service. It makes human resource management (HRM) as the important function in the service industries. HRM involves selection, training, giving adequate levels of autonomy, setting standards/ objectives, accessing individual performance, helping people where help is needed and, finally, rewarding them for their achievements. Selected people are trained to enhance skills, improve attitudes towards customers and learn about the services offered. The right people have 
right perception of customer expectations and perceptions. They know about service quality strategies and their efforts are aligned with management goals and what the organization is trying to accomplish. While in the traditional models of service quality gap (Figure 3), Gap 7 is defined as the difference between management perception of customer expectations and employee perception of customer expectations, there is no attention to the difference between management and employees perceptions. Therefore, Gap 14 is defined as "Difference between management perceptions of customer perceptions and employee perceptions of customer perceptions".

Managers should encourage employee to collect feedback on customers' expectations and perceptions and there should be an effective internal relationship between managers and employees. It has to do with managers listening to employees, receiving feedback about the employees' perceptions of the organization's performance on its fundamental quality dimensions. If such relationship becomes effective, the gap is expected to be nil.

\section{Conclusions}

In this paper, the traditional models of service quality gaps were reviewed and critically discussed. While this investigation shows that the traditional models are not comprehensive, it tried to develop them in order to be more comprehensive for different applications. According to Figure 4, the five new components included in the developed model were ideal standards; translation of strategy and policy into service quality specifications; service quality strategy and policy; employee perceptions of customer perceptions; and management perceptions of customer perceptions. Also, the eight new additional service quality gaps were as follows:

- Gap 2: Management perception versus Service quality strategy and policy;

- Gap 3: Service quality strategy and policy versus service specifications;

- Gap 4: service specifications versus ideal standards;

- Gap 5: service specifications external communication;

- Gap 11: Customers' perceptions versus management perceptions;

- Gap 12: The discrepancy between management perceptions and Service quality strategy;

- Gap 13: Customers' perceptions versus employee perceptions; and

- Gap 14: The discrepancy between employee's perceptions and management perceptions of customer

Service quality gaps affect service delivery, so departmental managers must prevent, detect and eliminate them as early as possible in any service operation. The impact of service quality gaps on strategy formation and implementation makes it increasingly important for the top management and staff planners to do the same.

Although this paper developed the model of service quality gaps based on a critical discussion, it is necessary to verify and validate the proposed model. This should be done in two stages; verifying the new components, links and gaps by experts and validating the developed model in practical investigations. Also, while this investigation tried to provide a comprehensive model of service quality gaps, it still has the potentiality of being more developed and more comprehensive. However, the empirical implementation of the model proposed may present some difficulties. The main problem to implement the SERVQUAL approach comprises the difficulty to measure the traditional five gaps. The proposed model adds more gaps thus becoming more difficult to evaluate than the traditional models.

The conceptuality of the questionnaires which will be developed for the measurement of the gaps is the major limitation of the gaps models including the proposed model. Additionally, although there exist standard questionnaires based on SERVQUAL approach for measuring few gaps such as Gap 8 (Gap5 in the traditional models), the design of questionnaire for other gaps is still a critical subject, which needs further investigation. It is important to note that even in the traditional models such as Parasuraman et al. (1985), measurement of some of the gaps like Gap2, Gap3 and Gap4 (Figure 1) needs development and only a few investigations have been conducted on such subject (e.g. Shahin and Abolhasani, 2008). Therefore, it seems the proposed model provides a great opportunity to researchers for further investigations on subjects such as development and enhancements of service quality models as well as measurement approaches.

\section{References}

Asubonteng, P., McCleaty, K.J. \& Swan, J.E. (1996). SERVQUAL revisited: a critical review of service quality. Journal of Service Marketing, 10(6), 62-81.

Babakus, E. \& Inhofe, M. (1991). The role of Expectations and Attribute Importance in the Measurement of Service Quality. in Gilly, M.C. (Ed.). Proceedings of the Summer Educator's Conference (pp. 142-144). Chicago, IL: American Marketing Association. 


\section{Ml Macrothink}

Boulding, W., Kalra, A., Staelin, R. \& Zeithaaml,V.A. (1993). A dynamic process model of service quality: from expectations to behaioural intentions. Journal of Marketing Research, 30(2), 7-27.

Brown, S.W. \& Bitner, M.J. (2007). Mandating a service revolution for marketing. in Lush, R.F. \& Vargo, S.L. (Eds). The Service-Dominant Logic of Marketing: Dialog, Debate and Directions (pp. 393-405). Armonk, NY: M.E. Sharp.

Brown, T.J., Churchill, G.A. \& Peter, J.P. (1993). Improving the Measurement of Service Quality. Journal of Retailing, 69(1), 127-139.

Carman, J.M. (1990). Consumer Perceptions of Service Quality: An Assessment of the SERVQUAL Dimensions. Journal of Retailing, 66(1), 33-35.

Chang, T.Z. \& Chen, S.J. (1998). Market orientation, service quality and business profitability: a conceptual model and empirical evidence. Journal of Service Marketing, 12(4), 246-264.

Cronin, J.J. \& Taylor, S.A. (1992). Measuring service quality: a re-examination and extension. Journal of Marketing, 6(7), 55-68.

Dabholkar, P.A., Shepherd, D.C. \& Thorpe, D.I. (2000). A Comprehensive Framework for Service Quality: An Investigation of Critical, Conceptual and Measurement Issues through a Longitudinal Study. Journal of Retailing, 76(2), 139-173.

Dotchin, J.A. \& Oakland, J.S. (1994a). Total quality management in services. Part 1: understanding and classifying services. International Journal of Quality \& Reliability Management, 11(3), 9-26.

Dotchin, J.A. \& Oakland, J.S., (1994b). Total quality management in services. Part 2: service quality. International Journal of Quality \& Reliability Management, 11(3), 27-42.

Frost, F.A. \& Kumar, M. (2000). INTSERVQUAL: an internal adaptation of the GAP model in a large service organization. Journal of Service Marketing, 14(5), 358-377.

Gammie, A. (1992). Stop at nothing in the search for quality. Human Resource, 5(Spring), 35-38.

Garvin, D.A. (1987). Competing on the eight dimensions of quality. Harvard Business Review, 65(Nov-Dec), 101-109.

Ghobadian, A., Speller, S. \& Jones, M. (1994). Service Quality Concepts and Models. International Journal of Quality \& Reliability Management, 11(9), 43-66.

Gronroos, C. (1990). Service Management and Marketing: Managing the Moment of Truth in Service Competition. New York, NY: Maxwell Macmillan Internal Editions.

Gummesson, E. (1998). Productivity, quality and relationship marketing in service operations. International Journal of Contemporary Hospitality Management, 10(1), 4-15.

Hallowell, R. (1996). The relationships of customer satisfaction, customer loyalty and profitability: an empirical study. International Journal of Service Industry Management, 7(4), 27-42.

Haywood-Farmer, J. (1988). A conceptual model of service quality. International Journal of Operations \& Production Management, 8(6), 19-29.

Haywood-Farmer, J. \& Stuart, F.I., (1990). An instrument to measure the degree of professionalism in a professional service. Service Industries Journal, 10(2), 336-347.

Hung, Y.H., Huang, M.L. \& Chen, K.S. (2003). Service quality evaluation by service quality performance matrix. Total quality Management \& Business Excellence, 14(1), 79-89.

Jain, S.K. \& Gupta, G. (2004). Measuring Service Quality: SERVQUAL vs. SERVPERF Scales. Vikalpa, 29(2), 25-37.

Lasser, W.M., Manolis, C. \& Winsor, R.D. (2000). Service quality perspectives and satisfaction in private banking. Journal of Service Marketing, 14(3), 244-271.

Leonard, F.S. \& Sasser, W.E. (1982). The incline of quality. Harvard Business Review, 60(5), 163-171.

Lewis, B.R. (1989). Quality in Service Sector - A Review. International Journal of Brand Marketing, 7(5), 4-12.

Lewis, R.C. \& Booms, B.H. (1983). The marketing aspects of service quality. in Berry, L., Shostack, G. \& Upah, G. (Eds). Emrging Perspectives on Service Marketing (pp. 99-107). Chicago, LL: American Marketing Associaton. 
Lewis, B.R. \& Mitchell, V.W. (1990). Defining and measuring the quality of customer service. Marketing Intelligence \& Planning, 8(6), 11-17.

Luk, Sh.T.K. \& Layton, R. (2002). Perception Gaps in customer expectations: Managers versus service providers and customers. The Service Industries Journal, 22(2), 109-128.

Newman, K. (2001). Interrogating SERVQUAL: a critical assessment of service quality measurement in a high street retail bank. International Journal of Bank Marketing, 19(3), 126-139.

Parasuraman, A., Zeithaml, V.A. \& Berry, L.L. (1985). A conceptual model of service quality and its implications for future research. Journal of Marketing, 49(4), 41-50.

Parasuraman, A., Zeithaml, V.A. \& Berry, L.L. (1988). SERVQUAL: a multi-item scale for measuring customer perceptions of service quality. Journal of Retailing, 64(1), 12-40.

Parasuraman, A., Zeithaml, V.A. \& Berry, L.L. (1993). Research note: more on improving service quality measurement. Journal of Retailing, 69(1), 140-147.

Philip, G. \& Hazlett, S.A. (1997). The measurement of service quality: a new P-C-P attributes model. International Journal of Quality \& Reliability Management, 14(3), 260-286.

Pitt, L.F. \& Jeantriut, B. (1994). Management of customer expectations in service firms: a study and a checklist. The Service Industries Journal, 14(2), 170-189.

Seilier, V.L. (2004). Examining Service Quality for homebuyers in the residential real state brokerage industry. $\mathrm{PhD}$ thesis, Sydney: University of Western Sydney.

Seth, N. \& Deshmukh, S.G. (2005). Service quality models: a review. International Journal of Quality \& Reliability Management, 22(9), 913-949.

Shahin, A. (2006). SERVQUAL and model of service quality gaps: A framework for determining and prioritizing critical factors in delivering quality services. in: Partha Sarathy V. (Ed.). Service quality - An introduction (pp. 117-131). Andhra Pradesh: ICFAI University Press.

Shahin, A. (2009). Dynamic IPA for Conforming Time Based Customer Changing Needs, Proceedings of the $3^{\text {rd }}$ Annual Quality Congress Middle East (pp. 114-123). 6-7 April, Dubai.

Shahin, A. \& Abolhasani, Z. (2008). Internal service quality gaps and analysis of the relationship with employee job satisfaction - with a case study in the Iran Insurance Co. of Isfahan. PhD thesis, Isfahan: University of Isfahan.

Shahin, A., Dehghan, A. \& Albadvi, A. (2006). Service Quality Gaps and Six Sigma with a Case Study on CCG (Customer Centric Group) Co. Proceedings of the Second International Conference on Six Sigma (pp. 50-64). $5^{\text {th }}-7^{\text {th }}$ June, Glasgow.

Sureshchander, G.S., Rajendran, C. \& Anatharaman, R.N. (2002). The relationship between service quality and customer satisfaction: a factor specific approach. Journal of Service Marketing, 16(4), 363-379.

Teas, K.R. (1993). Expectations, Performance Evaluation and customer's Perceptions of Quality. Journal of Marketing, 57(9), 18-34.

Teas, K.R. (1994). Expectations as a Comparison Standard in Measuring Service Quality. Journal of Marketing, 58(1), 132-139.

Van Iwaarden, J., van der Wiele, T., Ball, L., \& Millen, R. (2003). Applying SERVQUAL to web sites: An exploratory study. International Journal of Quality \& Reliability Management, 20(8), 919-935.

Wisniewiski, M. \& Donnelly, M. (1996). Measuring service quality in the public sector: the potential for SERVQUAL. Total quality Management, 7(4), 357-365.

Zahari, W., Yusoff, W., \& Ismail, M. (2008). FM-SERVQUAL: a new approach of service quality measurement framework in local authorities. Journal of Corporate Real Estate, 10(2), 130-144.

Zeithaml, V.A. \& Bitner, M.J. (2001). Services Marketing: Integrating Customer Focus Across the Firms. Boston: Tata-McGraw Hill.

Zemek, R. \& Schaaf, D. (1989). The Service Edge-101 Companies that Profit from Customer Care. New York, NY: NAL Books. 
Table 1. The results of the binomial test

\begin{tabular}{|c|c|c|c|c|}
\hline Soft factor & Agreed proportion & Disagreed proportion & Test proportion & Exact Sig. (2-tailed) \\
\hline 1 & 0.81 & 0.19 & 0.50 & 0.021 \\
\hline 2 & 0.81 & 0.19 & 0.50 & 0.021 \\
\hline 3 & 0.81 & 0.19 & 0.50 & 0.021 \\
\hline 4 & 0.81 & 0.19 & 0.50 & 0.021 \\
\hline 5 & 0.88 & 0.13 & 0.50 & 0.004 \\
\hline 6 & 0.81 & 0.19 & 0.50 & 0.021 \\
\hline 7 & 0.88 & 0.13 & 0.50 & 0.004 \\
\hline 8 & 1.00 & 1.00 & 0.50 & 0.000 \\
\hline 9 & 0.88 & 0.13 & 0.50 & 0.004 \\
\hline 10 & 1.00 & 1.00 & 0.50 & 0.000 \\
\hline
\end{tabular}

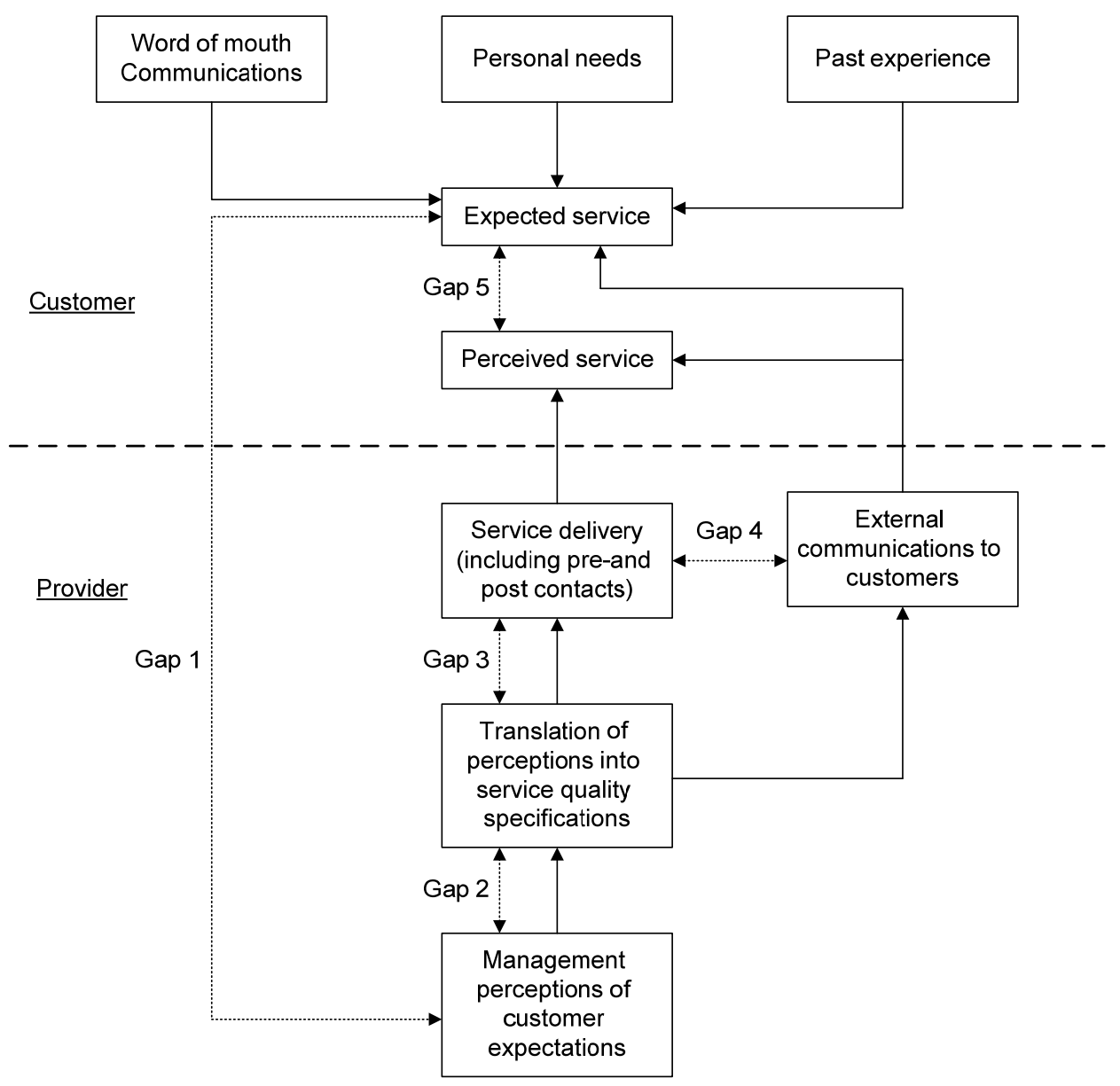

Figure 1. Model of service quality gaps by Parasuraman et al. (1985). 


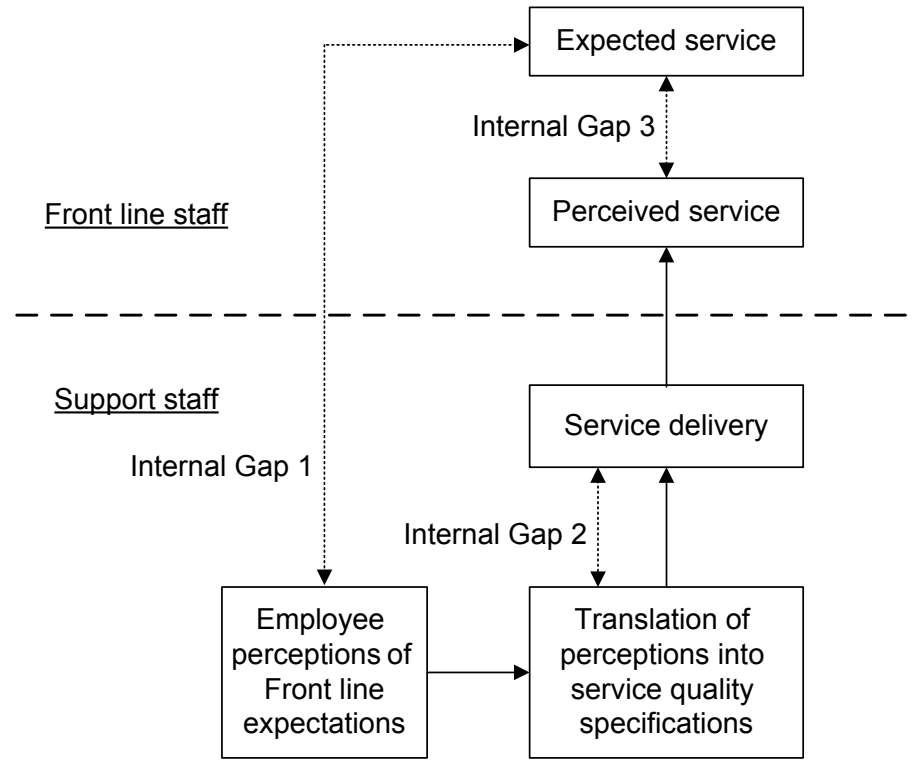

Figure 2. Model of internal service quality gaps by Frost and Kumar (2000).

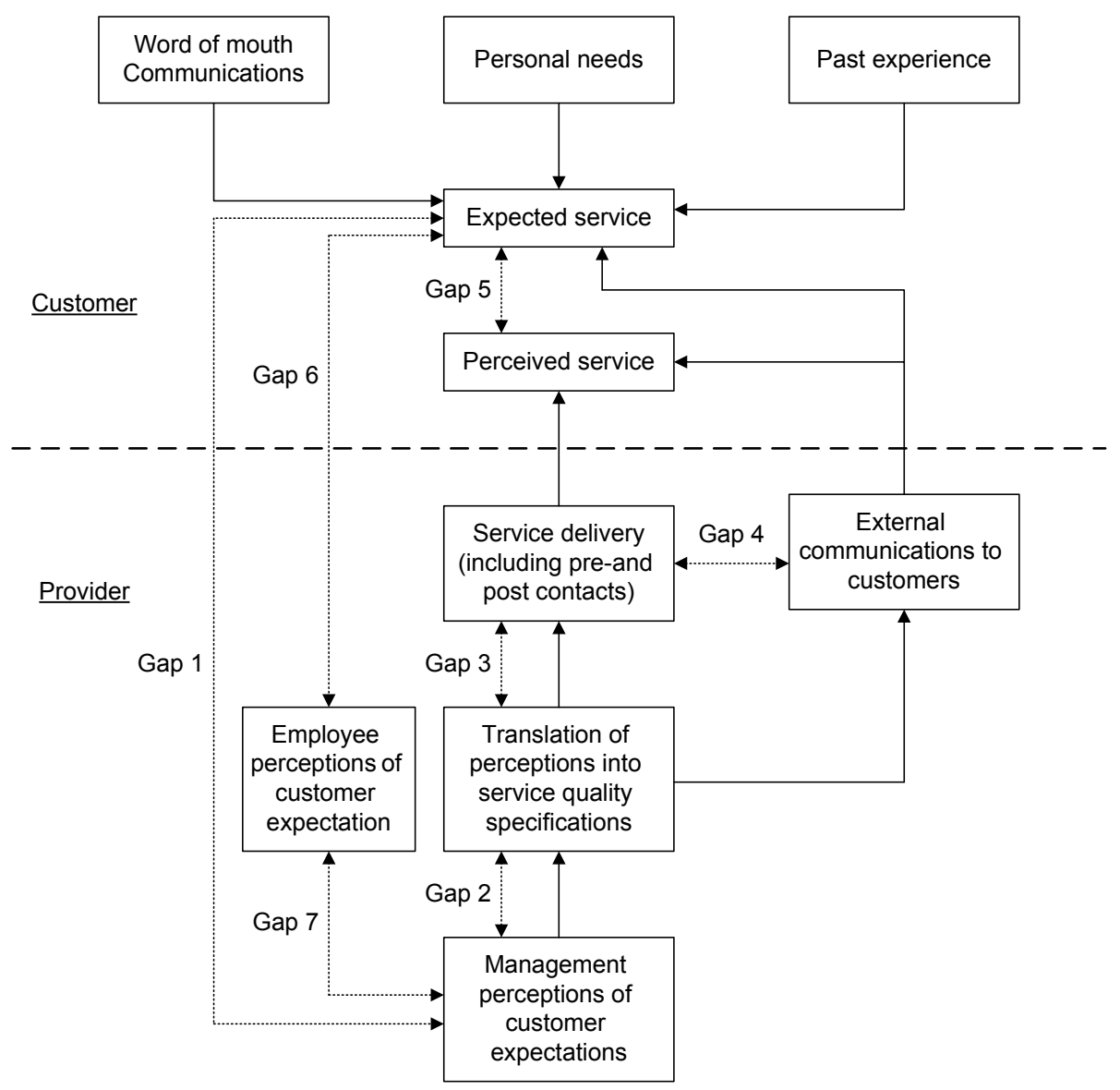

Figure 3. Model of service quality gaps by Luk and Layton (2002). 


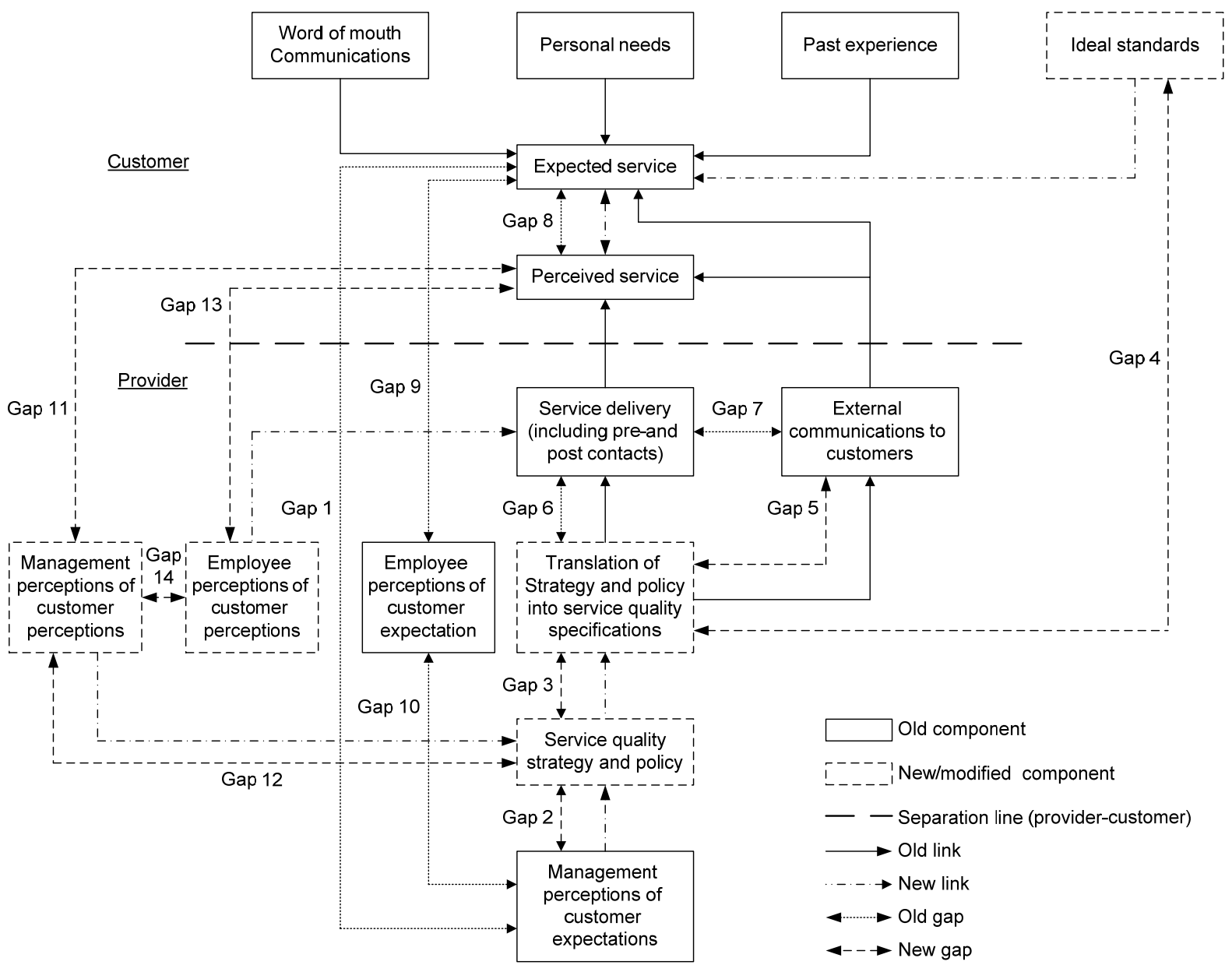

Figure 4. Proposed model of service quality gaps. 